\title{
Oligotrophication of Lake Zürich as reflected in Secchi depth measurements
}

\author{
F. Schanz 1
}

Keywords : Lake Zürich, oligotrophication, Secchi disk, transparency, Oscillatoria rubescens, clear water phase.

Secchi depths recorded in Lake Zürich are determined mainly by concentrations of autochtonous material such as plankton and other material related to biomass production. The surface contrast transmittance factor has a negligible effect on a Secchi depth of up to $7 \mathrm{~m}$ and is of minor importance up to $13 \mathrm{~m}$. Alterations in transparency values after 1970 as a result of the reduced nutrient input were most pronounced in the autumn-winter period (October 28 to February 19) as well as in the clear water phase (April 29 to July 29). After 1970, almost all buildings in the Lake Zürich drainage area were connected to a sewage treatment plant with a three stage purification. In the autumn-winter period, the Secchi depth is related to the development of Oscillatoria rubescens filaments and is not correlated with changes in trophic state. The restoration measures led to a statistically significant increase in the Secchi depth during the clear water phase, and additionally to a prolongation of the period with the highest tranparency values (May 20 to July 4). The Secchi technique is simple but seems to be valuable for recognizing long-term changes in the optical properties of a water body.

\section{Oligotrophisation du lac de Zurich à partir des mesures de profondeurs au disque de Secchi}

Mots clés : Lac de Zurich, oligotrophisation, disque de Secchi, transparence, Oscillatoria rubescens, période d'eau claire.

Dans le lac de Zurich, le matériel particulaire autochtone formé lors de la production primaire détermine la profondeur de visibilité du disque de Secchi. Le facteur d'atténuation des contrastes n'a aucun effet sur la profondeur du Secchi jusqu'à $9 \mathrm{~m}$ et une faible importance jusqu'à $13 \mathrm{~m}$. Après la mise en fonctionnement, en 1970, des stations d'épuration d'eau, les changements des valeurs de transparence deviennent plus prononcés surtout pendant l'hiver (28 octobre 10 février) et pendant la période d'eau claire (29 avril - 29 juillet). En hiver, la profondeur du Secchi est liée au développement des filaments d'Oscillatoria rubescens et n'est pas corrélée au changement de l'état trophique. En période d'eau claire, les mesures de restauration du lac entraînent une augmentation significative des valeurs du Secchi ; on observe, en outre, un allongement de la durée avec de fortes transparences pendant la période du 20 mai au 4 juillet. La technique de mesure du Secchi est simple mais bien valable pour apprécier les changements à long terme des qualités optiques d'un système lentique.

\section{Introduction}

The procedure by which the Secchi disk transparency is determined is simple : a white disk (usually $30 \mathrm{~cm}$ in diameter) is let down from the surface. It is common to determine the point of disappearance as the disk is lowered, allow it to drop a little farther, and then determine the point of reappearance

\footnotetext{
1. Institute of Plant Biology, Limnological Station, Seestr. 187,
} CH-8802 Kilchberg/Switzerland. as the disk is raised. The mean of the two readings in taken as the Secchi- disk transparency (Hutchinson 1957). The technique, which was developed in the last century by Angelo Secchi (bibliographical notes are given by Tyler 1968 and Preisendorfer 1984) for optical investigations in the Mediterranean sea, was employed in lakes for the first time a few years after its original publication (Forel 1895). In Lake Zürich the first Secchi depth measurements were made during the period $1897-1900$ by Pfenninger 
(1902). Further investigations were carried out irregularly from 1914 to 1928 (Dietlicher 1974) and routinely almost every month from 1936 up to now (Thomas 1971, Schanz \& Thomas 1980).

With respect to its optical properties the situation of Lake Zürich is unusual. Its main inlet is the outlet of the Zürich-Obersee, or Upper Lake Zürich, where most of the allochtonous inorganic particles settle out. The Secchi depth measurements were carried out at the lower end of the lake more than $20 \mathrm{~km}$ from the main inlet, so it can be assumed that the optical properties there are determined by the concentrations of autochtonous material, mainly plankton and other material related to biomass production (e.g. $\mathrm{CaCO}_{3}$ precipitation; Weidemann et al. 1985). Some rare exceptions occur during heavy thunderstorms when the incoming suspended material increases the turbidity of the epilimnetic water layer for a few hours. The relationship between transparency and chlorophyll a has been shown to be very close (Schanz 1982). This serves as a direct proof of the great influence of plankton density on Secchi depth.

The history of the pollution of Lake Zürich is presented elsewhere in detail (Thomas 1965). There are several indications of a dramatic increase in phytoplankton biomass at the end of last century. Periods of rapid eutrophication occurred after the First and the Second World Wars. Between about 1955 and 1965 most of the communities around Lake Zürich constructed sewage treatment plants (three purification stages : mechanical, biological and phosphorus precipitation). This led to a considerable improvement of the trophic status of Lake Zürich, which was first announced by Thomas (1971) based on only 2-3 years of data. 15 years later a larger data base allowed more precise statements on the development of the trophic status of the lake to be made (Schanz \& Thomas 1986). The phosphate concentration measured at the end of spring circulation dropped down from $80 \mu \mathrm{g} \mathrm{PO}_{4}{ }^{3--P} / 1$ in 1970 to $50 \mu \mathrm{g} / 1$ in 1985 . In addition we observed a marked improvement in the oxygen conditions of the deep-water layer (100-137 m depth) : the mean minimum values in autumn, which were $1.3 \mathrm{mg} / \mathrm{l}$ (with standard deviation, $\mathrm{s}=1.2$ ) in the period from 1936 to 1965 , increased up to $4.2 \mathrm{mg} / \mathrm{l}(\mathrm{s}=1.0)$ in the period 1965 to 1986 . We supposed that this must be an effect of a reduction in biomass production in the euphotic zone as a consequence of reduced nutrient input.
Increases in Secchi depth are expected above all during periods of negligible internal nutrient recycling from the sediments or from the oxygen depletion zone in thermocline (this concerns mainly the stagnation period during May, June and July). Some preliminary investigations conducted in 1986 did not show any changes in Secchi depth during the recovery period (since 1965). A more detailed review of the data material, however, revealed considerable changes in Secchi depth that were apparently not recognized earlier. Therefore we planned more extended as well as more careful statistical investigations to compare the period of maximum eutrophication (from 1936 up to 1965) with the recovery period (after 1965).

\section{Theoretical background}

The Secchi disk is a device used to visually measure the clarity of natural waters. Thus the visual sense of the human operator is an integral part of the measurement procedure. Secchi disk readings are subjectively determined apparent optical properties of the water under study.

The basic equation of Secchi disk science is the photopic contrast reduction formula (Preisendorfer 1986) which describes the attenuation of the contrast of a submerged object along a vertical path of sight in a homogeneous medium :

$$
\mathrm{C}_{\mathrm{z}}=\mathrm{C}_{0} \exp [-(\alpha+\mathrm{K}) \mathrm{z}]
$$

where $C_{z}$ is the apparent contrast (non-dimensional) as seen by an observer situated $\mathrm{z}$ meters from the disk along the path of sight; $\mathrm{C}_{0}$ is the inherent contrast of the Secchi disk against its background, $\alpha$ and $\mathrm{K}$ are photopic quantities (in $\mathrm{m}^{-1}$ ), namely the photopic beam attenuation and the photopic diffuse attenuation coefficients of the medium, respectively. The quantity $(\alpha+K)$ is a spectrally averaged and depth averaged apparent optical property of the medium. $\mathrm{C}_{0}$ is a non-dimensional constant, in general calculated as follows

$$
\mathrm{C}_{0}=\left(\mathrm{R}-\mathrm{R}_{\mathrm{oo}}\right)\left(\mathrm{R}_{\mathrm{oo}}\right)^{-1}
$$

where $R$ is the reflectance of the matt surface of the Secchi disk in water (mostly assumed to be 0.85 for a white disk) and Roo is the reflectance of the water background at the depth of the Secchi disk disappearance (usually 0.02 ). Inserting these values for $R$ and $R_{o o}$ in Eq. 2, we obtain $C_{0}=41.5$. 
The photopic contrast is reduced by air-water surface effects, e.g. by capillary waves and by the reflection of diffuse light from a flat calm surface. However, good Secchi disk practice will eliminate these effects so that the surface transmittance factor $\tau=1$. Eq.1 can be rewritten as

$$
\left.\mathrm{z}_{\mathrm{SD}}=\operatorname{In}\left[\tau \mathrm{C}_{0} \mathrm{C}_{\mathrm{T}^{-1}}\right](\alpha+\mathrm{K})^{-1}\right)
$$

where $\mathrm{z}_{\mathrm{SD}}$ is the depth of disappearance of the Secchi disk (in $\mathrm{m}$ ) and $\mathrm{C}_{\mathrm{T}}$ is the threshold (or liminal) contrast of the disk (Sauberer \& Ruttner 1941, $\mathrm{C}_{\mathrm{T}}$ $=0.0075 ;$ Højerslev, 1986, $\mathrm{C}_{\mathrm{T}}=0.0070 \pm$ 0.0003 ). $\mathrm{C}_{0}, \alpha$, and $\mathrm{K}$ are given by Eq.1. Using Eq. 3 with $\mathrm{C}_{0}=41.5, \mathrm{C}_{\mathrm{T}}=0.007$ and $\tau=1$ we get :

$$
\mathrm{z}_{\mathrm{SD}}=8.7(\alpha+\mathrm{K})^{-1}
$$

The Secchi disk readings are obviously inversely correlated with the sum of the beam attenuation and diffuse attenuation coefficients. Thus Secchi depths yield quantitative estimates of the apparent optical property $(\alpha+K)$ of the water body investigated.

\section{Material and methods}

Determinations of Secchi depth were carried out in Lake Zürich as described by Hutchinson (1957) using a white disk $30 \mathrm{~cm}$ diameter. Measurements were carried out almost every week since 1979 about $300 \mathrm{~m}$ offshore from the Limnological Station at Kilchberg. Normally the Secchi depth was determined between 11 a.m. and 2 p.m. To allow us to set the contrast transmittance factor $\tau=1$ we used a bathyscope at the water surface. Data from earlier periods up to 1970 were available from the monthly monitoring program of the Zürich Cantonal Laboratory and from the publications of Pfenninger (1902) and Dietlicher (1974). These determinations were carried out at the deepest part of Lake Zürich (about $10 \mathrm{~km}$ from Kilchberg) without a bathyscope. As outlined by Preisendorfer (1986) it must be assumed that the surface contrast transmittance factor exerted a considerable influence on the Secchi depth value obtained. In order to compare the data measured before 1970 with those of more recent years we therefore needed some quantitative information about the influence of $\tau$ on the Secchi disk readings. Consequently, we carried out a set of measurements with and without a bathyscope. The data from the period 1970 to 1979 originate from the-City of Zürich Water Supply (unpublished) ; the effect of surface disturbances on these measurements has already been eliminated. Statistical interpretations are based on Sachs (1984) ; calculations were performed using StatViewII (Feldman et al. 1987) on a Macintosh IIcx computer.

\section{Results and discussion}

\subsection{Seasonal variations in Secchi depth}

Seasonal variations in Secchi depth during each year of the period 1979 to 1991 are similar. Fig. 1 illustrates the representative year 1990 . Values are high ( $>6 \mathrm{~m}$ ) in the winter period from January to March. At the beginning of this period the optical properties of the lake are determined by decreasing densities of Oscillatoria rubescens De Candolle filaments ; thereafter some development of Stephanodiscus hantzschii Grunow occurs which in 1990 gives a peak on February 19 (day 50). From about the middle of March to the end of April Secchi depths of $2 \mathrm{~m}$ to $4 \mathrm{~m}$ are observed. These low values are due to the phytoplankton spring bloom which is described in detail by Bleiker \& Schanz (1989). The time range of the subsequent clear water period was fixed more or less arbitrarily from day 120 (April 29) to day 210 (July 29). However in all the years studied, the spring bloom was mostly finished before day 120 and the summer bloom started after day 210 . The summer bloom is most pronounced at the end of August when declining air temperatures result in a negative heat income to the lake. The resulting circulation transports accumulated nutrients upwards from the metalimnion promoting phytoplankton growth considerably. In the middle of October (day 288 , October 15 ), the autumn period begins with the complete loss of stratification and with decreasing light intensities. In most years there was an increase in Secchi depth during the autumn period (unfortunately not recognizable in Fig. 1).

The seasonal variations mentioned above are typical for most lakes with a morphology and nutrient regime similar to those of mesotrophic Lake Zürich (e.g. Lake Constance around 1980 : Tilzer 1988). Oligotrophic lakes are characterized by high transparency values, above all in the winter months from January to March, and a pronounced clear water phase (high Secchi disk readings during a period of several weeks). This was indeed the case in the formerly oligotrophic Läkes Constance (Elster 1960, 1961) and Geneva (Forel 1901). In eutrophic lakes, Secchi values are small during the 


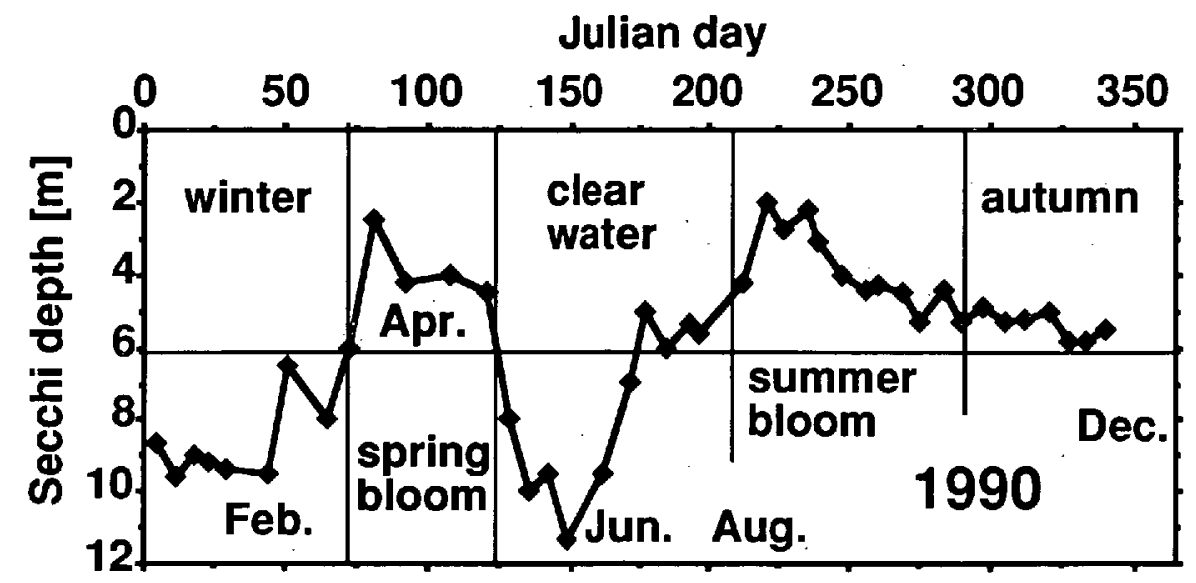

Fig. 1. Seasonal variations in Secchi depth in Lake Zürich during 1990.

Fig. 1. Variations saisonnières de la profondeur de Secchi dans le lac de Zurich en 1990.

autumn and winter periods and the clear water phase is short (several days according to Wetzel 1983) ; sometimes a second summer maximum is recognizable (Sommer 1986). Secchi disk measurements in hypertrophic lakes are in general very small $(0.5$ to $2 \mathrm{~m}$ ) and show little variation (Kim \& Travers 1963, Klöti 1988).

\subsection{Influence of the surface contrast transmittance factor on Secchi depth}

The Secchi data material from Lake Zürich have to be separated into (1) the data measured before 1970 , in which surface effects were not accounted for, and (2) the data taken after 1970 with more or less complete elimination of surface influences. For the purposes of comparison, some knowledge about the quantitative effect of the surface constrast transmittance factor ( $\tau$ in Equ. 3) on Secchi disk readings in needed. In the period 1980 to 1982 , we conducted two simultaneous transparency measurements : one with the bathyscope and the second without it. According to Eq. 3 the difference between the two values is due to $\tau$. A preliminary survey of the data material showed that two relationships exist between the data derived from the two measurement procedures : 1) Fig. 2A, data in the range 1 to 7 meters ; 2) Fig. 2B, data in the range 7 to 16 meters. The regression line in Fig. $2 \mathrm{~A}$ implies that the transparency values determined without a bathyscope are in the mean $5 \%$ lower than those determined with a bathyscope. However the calculated slope of 1.05 does not differ significantly from 1 ( $95 \%$ confidence limits : 0.995 and 1.107). We can therefore conclude that the influence of $\tau$ on determinations of Secchi depths within the range 1-7 meters is negligible. The regression line in Fig. 2B indicates a mean difference of $13 \%$ between Secchi disk readings with and without a bathyscope ( $95 \%$ confidence limits : 1.019 to 1.235 ). It is also obvious from Fig. $2 \mathrm{~B}$ that the amount of scatter increases with increasing Secchi depth: This might be due to the large amount of variation in the surface contrast transmittance factor. Secchi depth determinations exceeding $13 \mathrm{~m}$ should therefore not be used without special care.

\subsection{Monthly mean comparisons of the three periods 1897-1900, 1955-1964 and 1981-1990}

The results of the calculations are presented in Fig. 3. Comparing the monthly means of the periods 1897 to 1900 with those of 1955 to 1964 , no significant differences could be found. However all monthly means of the period 1981 to 1990 were higher than those of the period 1955 to 1964 . These results are particularly pronounced in the winter period (January to March), in the clear water phase (May and June) and in autumn (October to December). It might be supposed that these changes are a result of the external restoration measures. In this context we should remember that many successes in 


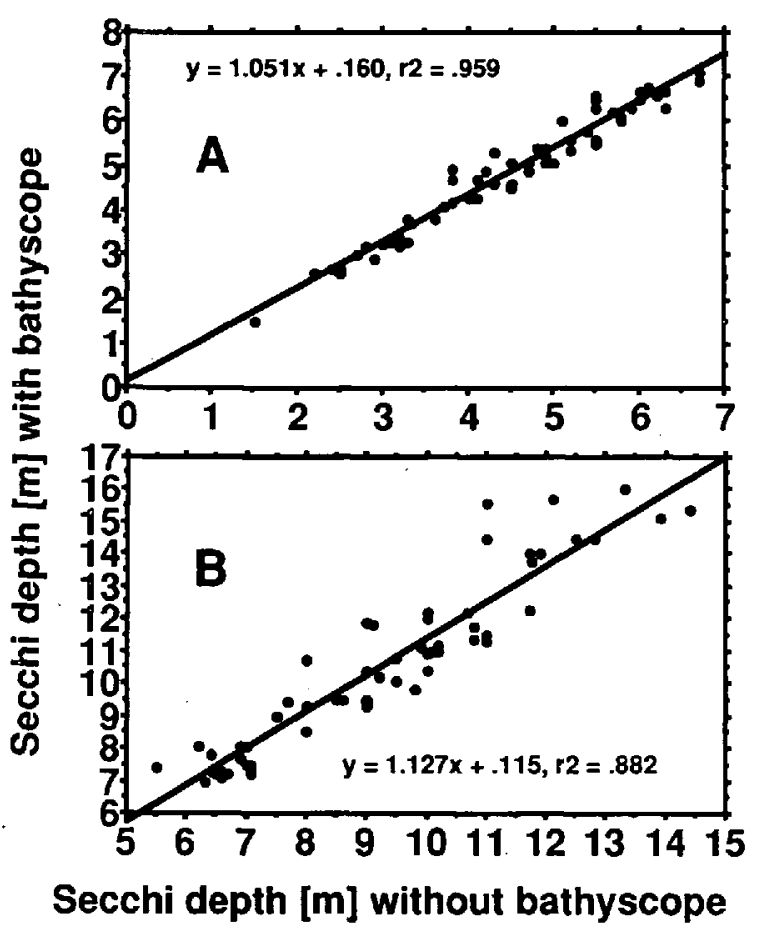

Fig. 2. Comparison of Secchi depths measured with and without a bathyscope. A : Low values (1-7 m, measurements with bathyscope). B : High values (7-16 m, measurements with bathyscope). Equation of regression line ( $y=$ Secchi depth with bathyscope, $\mathrm{x}=$ Secchi depth without bathyscope) and square of correlation coefficient $\left(r^{2}\right)(=$ coefficient of determination).

Fig. 2. Comparaison des profondeurs de Secchi mesurées avec ou sans bathyscope. A : Petites valeurs ( $1-7 \mathrm{~m}$, mesurées avec bathyscope). B : Grandes valeurs (7-16 m, mesurées avec bathyscope). Equation de la ligne de régression ( $y=$ profondeurs de Secchi avec bathyscope, $x=$ profondeurs de Secchi sans bathyscope) et le carré du coefficient de corrélation $\left(\mathrm{r}^{2}\right)$.

lake restoration by biomanipulation show that transparency changes can occur without any alteration in the nutrient regime (Shapiro \& Wright 1984). Therefore special investigations are needed to look for such biological effects. An additional problem is the fact that the monthly means over a ten year period represent a considerable simplification of the real situation : the periodicity in the Secchi disk depth (presented for 1990 in section 4.1) differ between years (Schanz 1982) depending on weather conditions. Each Secchi disk reading includes specific information which is lost by calculating monthly means over several years.

\subsection{Influence of Oscillatoria rubescens on Secchi disk depth in autumn and winter (1972 to 1992)}

Based on phytoplankton counts over the period extending from day 300 (Oct.28) to day 50 (Feb.19) of the following year and on the corresponding Secchi disk data, we found no relationship between species abundance and Secchi depth except in the case of Oscillatoria rubescens (Fig. 4) : Secchi depth was found to decrease with increasing $O$. rubescens biomass $(\mathrm{N}=34, \mathrm{P}<0.0001)$.

$O$. rubescens has been found in many Swiss lakes with various different nutient loadings (Lakes Lucerne, Thoune, Lugano, Mauen ; Zimmermann 1969) but the species seems to occur at high densities only in eutrophic lakes (Findenegg 1973). Pelletier (1968) was of the opinion that $O$. rubescens developed in almost all perialpine lakes, but was probably in some lakes so scarce (e.g. in Lake Geneva) that the algologists overlooked it. The abundance of $O$. rubescens can alterate in two subsequent years without any changes in the trophic state of that lake (Findenegg 1973). The relationship between the development of $O$. rubescens and the trophic state of lake is not yet understood. Since this alga dominates Secchi depth determinations in the autumnwinter period in Lake Zürich (Fig. 4), we were neither able to make any useful comparisons nor to look for trends in the trophic state from 1979 up to the present.

\subsection{Influences of the restoration measures on the clear water phase}

As mentioned above, the clear water phase is arbitrary fixed as the period from day 120 (April 29) to day 210 (July 29). It starts at the end of the phytoplankton spring bloom when zooplankton activity is very high and the concentrations of some nutrients are below their detection limits. At this time of year, Secchi depths usually increase from about 2 meters to more than 8 meters (in several days) as a consequence of the rapidly decreasing phytoplankton density. It can be assumed that some of the nutrients fixed by the phytoplankton organisms are fully mineralized in the euphotic zone and that the nutrients released are available to autotrophic species (Golterman 1984), but these nutrients seem not to be enough to support fast algal growth. In this situation, nutrients brought into the lake by rivers, streams (above all after thunderstorms) and the 


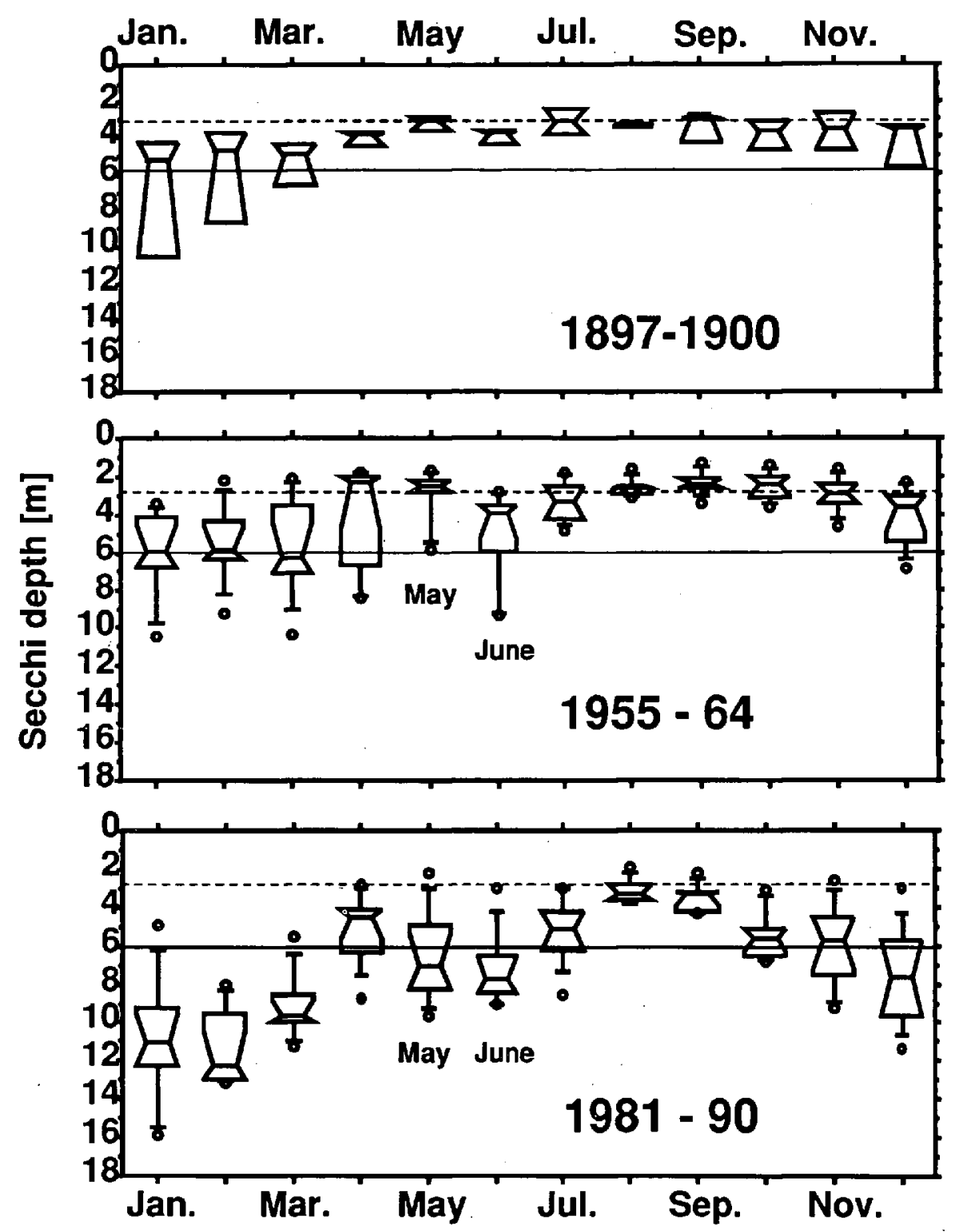

Fig. 3. Monthly variations in Secchi depth during the three periods 1897 to 1900,1955 to 1965 and 1981 to $1990.10,25,50,75$ and $90 \%$ percentiles are represented by horizontal bars from low to high Secchi depths.

Fig. 3. Variations mensuelles de la profondeur de Secchi pendant les trois périodes suivantes : 1897 à 1900 , 1955 à 1965 et 1981 à 1990. Les percentiles de 10,25, 5075 et $90 \%$ sont figurés par des traits horizontaux échelonnés des basses aux fortes valeurs de Secchi.

effluents of sewage treatment plants are of high importance for a more or less rapid increase in phytoplankton density. It can be assumed that the rate of biomass recovery ( = daily increase of phytoplankton density, in Lake Zürich characterizable by the daily decrease in Secchi depth) depends on the amount of incoming nutrients. Thus a fast biomass recovery was expected in Lake Zürich during the period of high eutrophication (before 1970) and a marked prolongation should be found as a response to the reduced nutrient input after 1970. Taking into account all plankton investigations there is no 


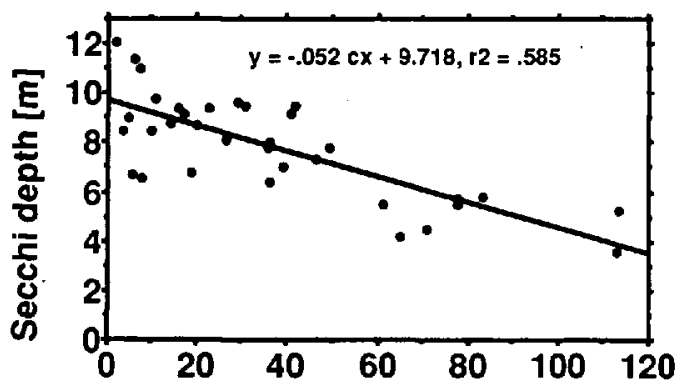

total filament length per unit volume $[\mathrm{mm} / \mathrm{ml}]$
Fig. 4. Influence of Oscillatoria rubescens biomass (mean $0-10 \mathrm{~m}$ depth) on Secchi depths in the period from day 300 (October 27) to day 50 of the following year (February 19). Total filament length $(\mathrm{mm} / \mathrm{ml})=$ Total counts of filaments $(\mathrm{N} / \mathrm{ml})$ $\times$ mean filament length $(\mathrm{mm} / \mathrm{N})$. Period 1972 to 1992 data from the City of Zürich Water Supply. Equation of regression line $(\mathrm{y}=$ Secchi depth, $\mathrm{x}=$ total filament length per unit volume, $c=$ conversion factor, $1 \mathrm{ml} \mathrm{m} / \mathrm{mm}$ ) and square of correlation coefficient $\left(\mathbf{r}^{2}\right)$.

Fig. 4. Influence de la biomasse d'Oscillatora rubescens (moyenne de la couche de 0 à $10 \mathrm{~m}$ de profondeur) sur la profondeur de Secchi pendant la période du jour 300 (27 octobre) jusqu'au jour 50 de l'année suivante (19 février). Longueur totale des filaments $(\mathrm{mm} / \mathrm{ml})=$ nombre total des filaments $(\mathrm{N} / \mathrm{ml}) \times$ longueur moyenne des filaments $(\mathrm{mm} / \mathrm{N})$. Les données de la période 1972 à 1992 proviennent du Service des Eaux de Zurich. Equation de la ligne de régression y $=$ profondeur de Secchi, $x=$ longueur totale des filaments par unité de volume, $\mathrm{c}=$ facteur de conversion, $1 \mathrm{ml} \mathrm{m} / \mathrm{mm}$ et $\mathrm{r}^{2}=$ carré du coefficient de corrélation.

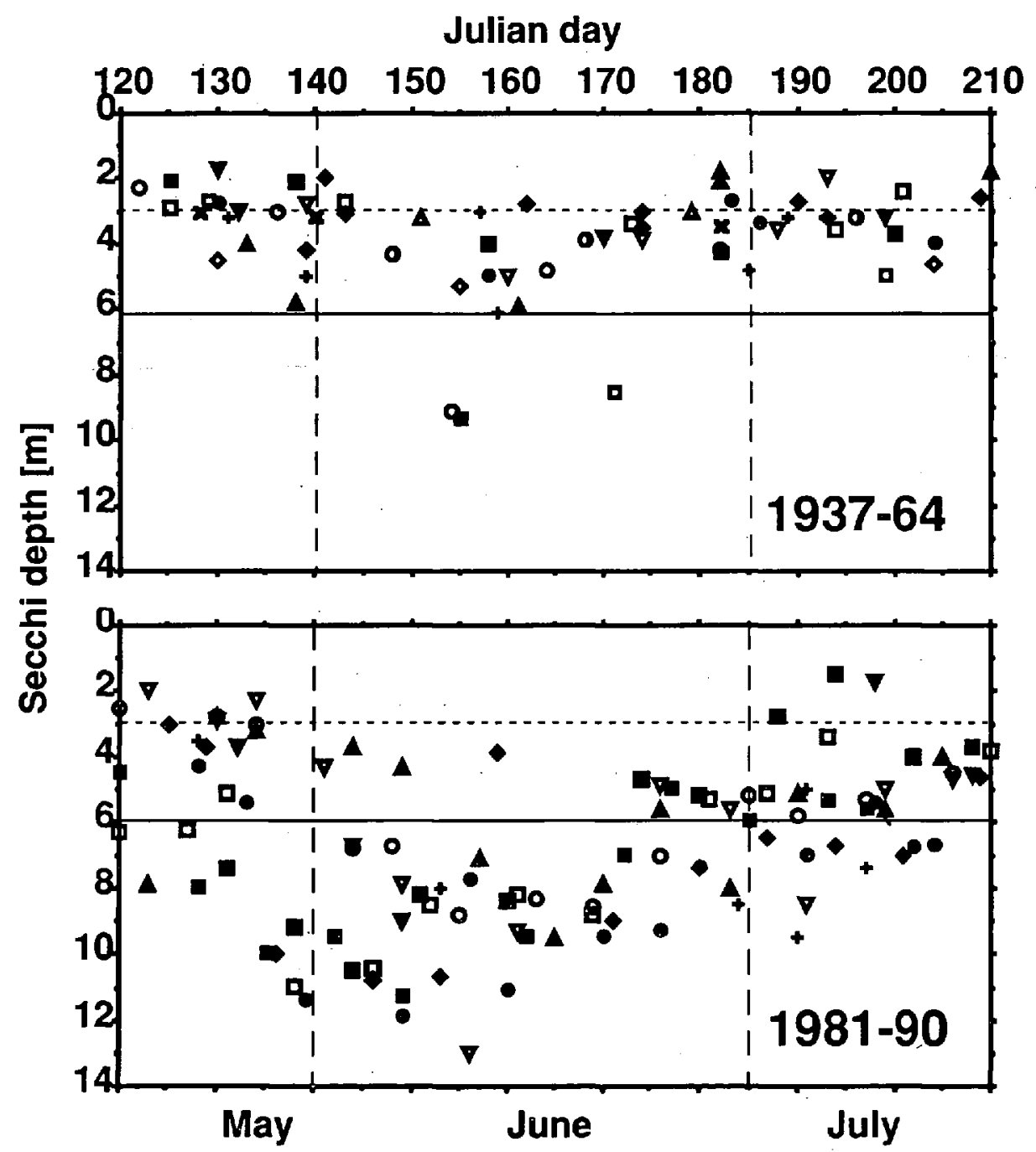

Fig. 5. Secchi depths measured during the clear water phase in the periods 1937 to 1964 and 1981 to 1990.

Fig. 5. Profondeurs de Secchi mesurées pendant les phases d'eau claire au cours des périodes 1937 à 1964 et 1981 à 1990 
indication of any changes in the species composition of the phytoplankton during the past 50 years in the clear water phase.

Comparing all Secchi depth data obtained during the clear water phase from 1955 to $1964(\mathrm{~N}=30)$ with those from 1981 to $1990(\mathrm{~N}=96)$ we noticed a significant difference in the means $(D F=224, t-$ value $=-5.598, \mathrm{P}<0.0001: \mathrm{x}_{55-64}=3.7, \mathrm{~s}=$ $1.9 ; \mathrm{x}_{81-90}=6.7, \mathrm{~s}=2.7$ ). However, nothing can be said about the duration of the clear water phase. A second statistical investigation included all Secchi disk readings available from 1937 to 1964 in order to have more data from the most eutrophic period of Lake Zürich. These data are presented in Fig. 5 which the time axis subdivided into three sections : (1) early, day 120 to 140 ; (2) middle, day 140 to 185 and (3) late, day 185 to 210 . In the period from 1937 to 1964 there is no difference between the sections (one-factor ANOVA, $\mathrm{N}=60, \mathrm{~F}$-test $=$ $2.115, P=0.13$ ). Only three readings point to the existence of a clear water phase. However, it can be supposed that in that period, clear water phases did appear every year, but they were so short that they could not be observed by the monthly samplings. In the period from 1981 to 1990 the three sections differ significantly from each other (one-factor ANOVA, $\mathrm{N}=108$, F-test $=16.72, \mathrm{P}<0.0001$ ). Obviously, in most of the years, the highest Secchi values were determined between day 140 (May 20) and day 185 (July 4). Further there is also a significant difference between the values obtained during the period 1937 to 1964 and those obtained from 1981 to 1990 (two-factor AVONA, $N=170, F$-test $=58.64, \mathrm{P}<0.0001$ ). As mentioned above, a statistically significant increase in Secchi depth in the clear water phase is found when comparing periods before and after 1970 . The three time sections early (from day 120 to day 140), middle (140-185) and late (185-210) differ considerably in the period 1981-1990 but not in the period before 1970 . It is recognizable in Fig. 5 that there were only a few values lying below 6 meters in the middle section of the period 1981-1990. We therefore conclude that the clear water phase was much longer then than it was the period before 1970 .

\section{Acknowledgments}

I thank Dr. David M. Livingstone for correcting the English text. Plankton count data were made available by the City of Zürich Water Supply (Dr. h.c. Maarten Schalekamp, Dr. Ulrich
Zimmermann). Bernhard Guggenbühl, Hans-Peter Rauber, HansPeter Mächler and Angela Mechsner helped in the field.

\section{References}

Bleiker W. \& Schanz F. 1989. - Influence of environmental factors on the phytoplankton spring bloom in Lake Zürich. Aquat. Sci., 51 : 47-58.

Dietlicher K. 1974. - Die Wassergüte des Zürich - und Walenses - Versuch einer Darstellung. Gas, Wasser, Abwasser, 12 : 553-592.

Elster H.J. 1960. - Der Bodensee als Organismus und die Veränderungen seines Stoffwechsels in den letzten Jahrzehnten. Gas-, Wasserfach, $101:$ 171-180.

Elster J.H. 1961. - Einige Beobachtungen über die Sichttiefe im Bodensee (Ober- und Untersee) während der Jahre 1932 bis 1935. Int. Rev. Ges. Hydrobiol., 46 : 43-50.

Feldmann D.S., Gagnon J., Hofmann R. \& Simpson J. 1987. - StatView II. Abacus Concepts, Berkeley : 247 p.

Findenegg I. 1973. - Vorkommen und biologisches Verhalten der Blaualge Oscillatoria rubescens D.C. in den österreichischen Alpenseen. Carinthia II, 163 : 317-330.

Forel F.-A. 1895. - Le Léman. F. Rouge, Lausanne, Vol. 2 : $651 \mathrm{p}$.

Forel F.-A. 1901. - Handbuch der Seenkunde. J. Engelhorn, Stuttgart : $249 \mathrm{p}$.

Golterman H.L. 1984. - Sediments, modifying and equilibrating factors in the chemistry of freshwater. Verh. Internat. Verein. Limnol., 22 : 23-59.

Hutchinson E.G. 1957. - A treatise on limnology. John Wiley \& Sons, Inc., New York, Vol. 1 : 1015 p.

Højerslev N.K. 1986. - Visibility of the sea with special reference to the Secchi disk. Proc. Soc. Photo-Opt. Instr. Eng., $637: 1-37$.

Kim K.T. \& Travers M. 1983. - La transparence et la charge sestonique de l'étang de Berre (côte méditerranéenne française). Hydrobiologia, $107: 75-95$.

Klöti P. 1988. - Experimentelle und theoretische Untersuchungen zur Sanierung des Waldweihers und des Gattikerweihers in Thalwil $(\mathrm{ZH})$. Ph. D. thesis, University of Zürich, $84 \mathrm{p}$.

Pelletier J. 1968. - Première colonisation du Léman par Oscillatoria rubescens D.C. Rev. Algol., 2 : 186-192.

Pfenninger A. 1902. - Beiträge zur Biologie des Zürichsees. Ph. D. thesis University of Zürich, $61 \mathrm{p}$.

Preisendorfer R.W. 1984. - Eyeball optics of natural waters : Secchi disk sciences. NOAA Technical Memorandum ERL PMEL-67 : 90 p.

Preisendorfer R.W. 1986. - Secchi disk science : Visual optics of natural waters. Limnol. Oceanogr., 31 : 909-926.

Sachs L. 1984. - Angewande Statistik. Springer-Verlag, Heidelberg : $552 \mathrm{p}$.

Sauberer F. \& Ruttner F. 1941. - Die Strahlungsverhältnisse der Binnengewässer. Akad. Verlagsgesellschaft, Leipzig : 240 p.

Schanz F. 1982. - Light conditions in Lake Zürich 1979-1981. Part I : Secchi disk transparency. Vierteljahrsschr. Naturforsch. Ges. Zürich, 127 : 357-367.

Schanz F. \& Thomas E.A. 1980. - Die Durchsichtigkeit des Zürichseewassers von 1897 bis 1980 . Vierteljahrsschr. Naturforsch. Ges. Zürich, $125:$ 239-248. 
Schanz F. \& Thomas E.A. 1986. - Der Zürichsee, Beispiel für einen Oligotrophierungserfolg durch externe Massnahmen. Landschaftsentw. Umweltforsch. $40: 531-540$.

Shapiro J. \& Wright D.I. 1984. — Lake restoration by biomanipulation. Freshwater Biol., 14 : 372-383.

Sommer U. 1986. - The periodicity of phytoplankton in Lake Constance (Bodensee) in comparison to other deep lakes of central Europe. In Munawar M. \& Talling J.F. (eds), Seasonality of freshwater phytoplankton. Dr. W. Junk, Dordrecht : $236 \mathrm{p}$.

Thomas E.A. 1965. - Der Verlauf der Eutrophierung des Zürichsees. Mitt. Oesterr. Sanitätsverwaltung, $66: 3-11$.

Thomas E.A. 1971. - Oligotrophierung des Zürichsees. Vierteljahrsschr. Naturforsch. Ges. Zürich, 116 : 165-179.
Tilzer M.M. 1988. - Secchi disk- chlorophyll relationships in a lake with highly variable phytoplankton biomass. Hydrobiologia, 162 : 163-171.

Tyler J.E. 1968. - The Secchi disk. Limnol. Oceanogr., 13 : 1-6. Weidemann A.D., Bannister T.T., Effler W.S. \& Johnson D.L. 1985. - Particulate and optical properties during $\mathrm{CaCO}_{3}$ precipitation in Otisco Lake. Limnol. Oceanogr., 30 : 1078-1083.

Wetzel R. 1983. - Limnology. Saunders College Publishing, Philadelphia : $784 \mathrm{p}$.

Zimmermann U. 1969. - Oekologische und physiologische Untersuchungen an der planktischen Blaualge Oscillatoria rubescens D.C. unter besonderer Berücksichtigung von Licht und Temperatur. Schweiz, Z. Hydrol., 31 : 1-58. 